\title{
可動翼型吸込み・送風エアポンプにおけるブレードの摺動トルク特性*
}

\author{
植 木 忠 博**, 稲 葉一 雄***
}

\section{Characteristics on Sliding Torque of Blades in a Slide-Blade Type Air Pump}

\author{
Tadahiro UEKI**, Kazuo INABA***
}

Slide-blade type air pumps are utilized in printing machines as an air source which provides both the action of air blowing and suction necessary for the paper handling. In the air pump, a large part of the motor power is occupied by the sliding friction between blades and cylinder surface of the casing. So, it is necessary to clarify the mechanism of the friction quantitatively in order to design practical dry air pumps with longer life and less energy consumption.

In the paper, first of all, the sliding force by a single blade was measured experimentally through the axle torque, and its mechanism was made clear. Then, the torque by multi-blades was investigated similarly, and its characteristics which should be affected by chamber pressure were analyzed. As a result, the following conclusions are obtained:

1). The sliding torque by a single blade indicates a cyclic change with rotor rotation, the absolute value of which is far larger than the theoretical one estimated by the centrifugal force to the blade solely.

2 ). The sliding torque by a single blade is affected significantly due to the constraint of the blade movement at the rotor slit. Specifically, the sliding torque is the largest around a point between the maximum protrusion hight and the maximum thrust speed. Therefore, the set angle of rotor slits is an important parameter for the blades behavior.

3 ). In actual air pumps with multi-blades, the air pressure in the blade chambers as well as in the bottom space of the rotor grooves seriously affect the blade motion along the rotor slit. Therefore, air holes connecting the bottom of the rotors slits as well as air slots formed on the blade side-face are effective for decreasing the sliding torque.

Key words : Air pump, Air blow, Air suction, Blade, Power consumption, Sliding torque, Paper handling, Printing machine

\section{1. 緒言}

枚葉印刷機や製本機械などの高速化に伴い, 周辺機器の 1つであるカットシートフィーダに対して，重送防止の性 能アップが求められている. そのエアアシスト機構では, 空気流をシートのサイドエッジに向けて噴きつけることに よってシート同士の付着を解きほぐす一方，紙面を負圧吸 引する.この 2 つ機能を同時に担うのが，可動翼型吸込 み・送風エアポンプである (以後, エアポンプと略称). 偏心ロータの回転によって翼室容積を変化させるという作 動原理は従来の可動翼型回転圧縮機と何ら変わるものでは ないがその構造と機能はかなり異なっている. 要は, 必要 な吸引負圧と排気送風量が 1 台のエアポンプによって供せ られるという利便性, 圧力・流量の微調整への対応性など

\footnotetext{
*平成23年 5 月 13 日 原稿受付

**芝浦工業大学工学部機械工学科

(所在地 テ135-8548 東京都江東区豊洲 3-7 - 5)

***(株)ナピコ

(所在地 ₹140-0013 東京都品川区南大井 1-16-1)
}

が買われて, ペーパハンドリングアシスト用エアポンプと して独自に発展し, 国内外の専業メーカがその製造に当 たっている. またエアポンプをへリュームガス回収ポンプ や排煙ポンプとして活用する新たな用途が検討されている. エアポンプの特徴は圧力比が小さいこと, ブレードの出 入 (突出し/後退) を遠心力のみに依存する単純構造であ ること，ブレードがケーシング内壁を直接摺動すること， およびブレードの枚数やロータのスリット角などに見出す ことができる。なお実用に際しては，吸込み・送風効率が 低いことに加え, 軸動力の大半がブレードとシリンダの高 速摺動摩擦によって占められるという機械効率の低さが弱 点となる1). そのため潤滑には特段の配慮を要する反面, エアポンプ本体の温度上昇に加え吸込み負圧によりミスト 化した潤滑油が, 紙面はもとより作業環境の污染源となる こと, あるいは劣化潤滑油の処理などへの対応上, 潤滑油 の消耗を極力抑えなければならないというジレンマも抱え ている.

このような背景から斯界では, オイルフリーのドライエ アポンプが待望され，既にその実用化が始まっているが, 鋳鉄ブレードからカーボンブレードへの転換が定着しつつ 
あるドライエアポンプにとって, ブレード摩擦トルクの抑 制は切実な課題である。 また送風エア中に混入したカーボ ンブレードの摩耗粉による紙面の污染, あるいはカーボン 粉塵に対するフィルター等の保守にも悩まされている.

\section{2. 研 究目的}

エアポンプの駆動トルクは，理論仕事とブレード摺動摩 擦の 2 成分からなる. このうち理論仕事トルクを試算して みると，たかだか $0.2 \mathrm{Nm}$ 程度であり，吐出圧をかなり高く 設定したとしても実駆動卜ルクに比べると遙かに小さいこ とから，その大半がシリンダに対するブレードの摺動摩擦 によって占められることは明白である。問題はこのブレー ドの摺動トルクを支配する要因である. エアポンプと機構 が類似している可動翼型回転圧縮機や油圧ベーンポンプに 対してブレード摺動トルクの力学的解析がかなり行われて はいるものの ${ }^{2), 3)}$ ，仕様や運転条件などの大きく異なる工 アポンプではそれらからブレード挙動を類推するにはかな り無理がある。しかも観察が難しいという制約もあり，ブ レードの動的挙動については推測に頼らざるを得ない，恐 らくブレードに働く遠心力が作用因子の 1 つであることは 間違いないが，定量的な効果は不明である，更にロータス リットにおけるブレードの出入あるいは翼室圧が駆動トル クにどれ程の影響を及ぼしているか，これらの究明が必要 である。その意味では，理論仕事や翼室圧の影響を受けな いシングルブレードによる摺動トルクを個別に分離・測定 することは，駆動卜ルク特性の本質を知るための参考とな る.

そこで，本研究ではまずエアポンプにおけるブレード摩 擦挙動をシングルブレードによる摺動トルクサイクルを通 して追跡した．次にその所見をもとに，翼室内圧の影響が 加わるマルチブレード摺動トルク特性を測定し，ドライエ アポンプの摺動トルク低減対策の手掛かりを得ようとする ものである.

\section{3. 実験方法および実験装置}

本報告ではまず，シングルブレードによる摺動トルクの 観察を先行させた，次いで，配列に配慮しながらブレード の枚数を順次増やし，枚数に対する摺動卜ルクの変化を追 跡したのは，枚数による摩擦トルクの加法性を検証し，ブ レード前後の翼室圧差やロータスリット底の隙間圧力がこ の摺動トルクへ及ぼす影響を抽出するためである。用いた 実験装置と実験条件は次のとおりである。

\section{1 実験装置}

実験には市販のエアポンプ（珠ナピコ製）を供したが, ブレードとシリンダ間の摺動トルクを測定するため，次の ような改造を加えた．まず，ロータとケーシングを独立に 回転できる構造とし，ケーシングとベース間に設置した荷 重計によって，回転中のブレードによる摺動トルクをロー

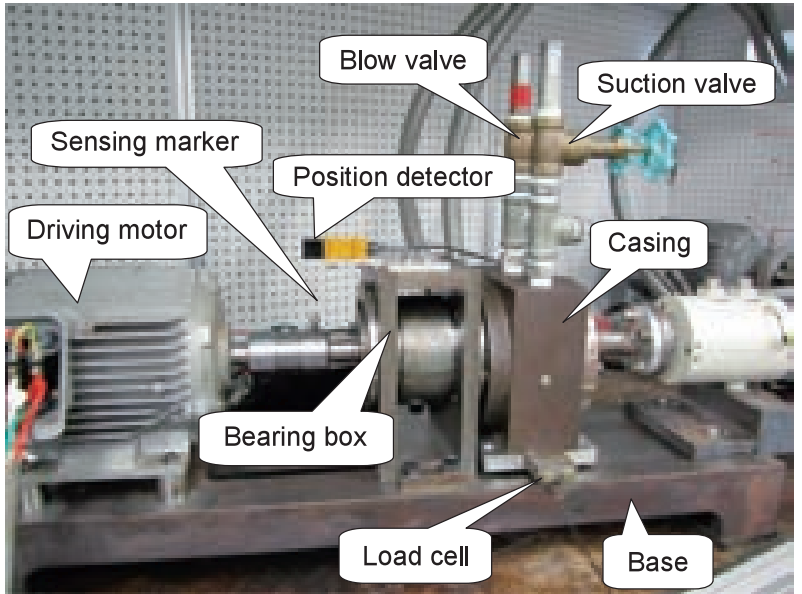

Fig. 1 A view of the experimental apparatus

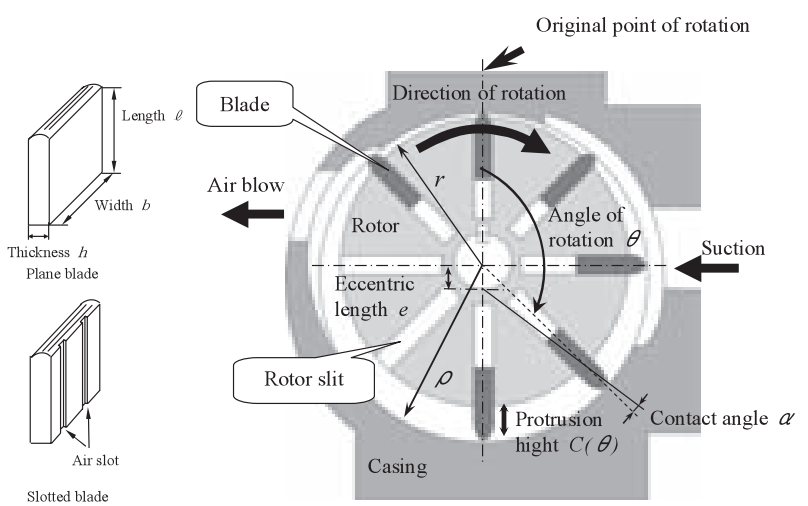

Fig. 2 Structure of a air pump

夕の回転角度 $\theta に$ 同期させながら検出できるようにした。 なおトルク計を介して駆動モー夕と主軸を直結させて駆動 トルクを直接計測し，荷重計による測定デー夕の信頼性を 確かめている4),5)

実験装置の全体構成をFig. 1に，エアポンプの機構部を Fig. 2に示す．なお空転駆動トルク：約 $0.7 \mathrm{Nm}$ （ブレード未 装着状態での駆動卜ルクで, 軸受摩擦力がその主体である) を予め計測し，実験デー夕を補正した。また荷重計を含む 摺動トルク測定装置系の固有振動数は約 $120 \mathrm{~Hz}$ であり, 回 転周波数を十分上回っている.

荷重計の出力はPCに取り达まれ，ロー夕 5 回転分の平均 值を実験值とし10度毎にデー夕処理を行った。

\section{2 実験条件}

試供エアポンプの仕様をTable. 1に一覧する。 また，ロー 夕の諸寸法をTable. 2に示す. エアポンプの摺動トルクに とって，ブレード出入（突出し／後退）抵抗とスリット角 $\gamma$ との関わりが大きいことは，ブレード重心に加わる遠心 力 $f_{C}$ とケーシング反力 $F_{0}$ の関係から当然予想できることで ある. 本研究では基本構造である求心スリットロー夕を主 体にし，偏心スリットロータも比較のため実験に供した (Fig. 3)。ドライポンプ用に開発された偏心スリットロータ は，摺動摩擦力 $F_{T}$ のケーシング反力 $F_{0}$ を高めることによっ 
てカーボンブレードの破壊を抑制する目的で設計された。

一方，隣り合う翼室間の差圧がブレード出入の円滑性に 大きな影響を及ぼす可能性は，当然予想されることである. そこで，ブレード出入に対する翼室圧の効果を確認する目 的でブレード通気溝（Fig. 2), およびロータスリット底隙 間を結ぶ導通孔（Fig. 3）も実験因子に加えている.ただし， 偏心スリットロータではカーボンブレードの破壊強度低下 の理由により，すべて通気溝を持たない平滑ブレードが用 いられている，そのため，ロータスリット底の隙間圧効果 は導通孔（Fig. 3）の有無によって検討した. 使用した鋳 鉄およびカーボンブレードの仕様もTable. 1に併記してい る.

実験条件として回転数 $N$, 風量 $Q$ は常用值程度としたが, 不確定な影響因子をできる限り除く意味で, 吸込みバルブ と送風バルブを開放し，求心スリットロータでは滴下給油，

Table. 1 Specifications of the air pump

\begin{tabular}{|c|c|c|c|c|}
\hline \multicolumn{2}{|c|}{$\begin{array}{ll}\text { specification } & \text { Type of rotor }\end{array}$} & \multicolumn{2}{|c|}{ Centripetal slit } & Eccentric slit \\
\hline \multicolumn{2}{|c|}{ Suction pressure $P S \quad \mathrm{kPa}$} & \multicolumn{2}{|c|}{$-40 \sim 0$} & $-40 \sim 0$ \\
\hline \multicolumn{2}{|c|}{ Blow pressure $P e \mathrm{kPa}$} & \multicolumn{2}{|c|}{$0 \sim 50$} & $0 \sim 50$ \\
\hline \multicolumn{2}{|c|}{ Flow rate $\quad Q \mathrm{~m}^{3} / \mathrm{min}$} & \multicolumn{3}{|c|}{$0 \sim 0.3$} \\
\hline \multicolumn{2}{|c|}{ Rotation speed $\quad N \quad \mathrm{rpm}$} & \multicolumn{2}{|c|}{$500 \sim 750$} & 1,500 \\
\hline \multirow{5}{*}{ Blade } & Number of slit & \multicolumn{2}{|c|}{8} & 4 \\
\hline & Material & \multicolumn{2}{|c|}{ FC250 } & $\begin{array}{l}\text { Resin-impregna- } \\
\text { ted Carbon }\end{array}$ \\
\hline & \multirow{2}{*}{$\begin{array}{l}\text { Size (Length } \times \text { Width } \times \\
\text { Thickness }) \mathrm{mm} \text { (Mass } \mathrm{g})\end{array}$} & \multicolumn{2}{|c|}{$40 \times 80 \times 5$} & $55 \times 75 \times 4$ \\
\hline & & \multicolumn{2}{|c|}{ (116) } & $(30)$ \\
\hline & Air slot & Plane & Slotted & Plane \\
\hline \multirow{2}{*}{ Casing } & Bore of cylinder $\mathrm{mm}$ & \multicolumn{2}{|c|}{127} & 118 \\
\hline & Material & & 250 & $\mathrm{~S} 45 \mathrm{C}$ \\
\hline \multicolumn{2}{|c|}{ Lubrication } & \multicolumn{2}{|c|}{ Drop-feed } & Dry \\
\hline
\end{tabular}

Table. 2 Specifications of the rotors

\begin{tabular}{|lrr|c|c|}
\hline \multicolumn{2}{|l|}{} & type & Centripetal & Eccentric \\
\hline Diameter of rotor & $2 \mathrm{r}$ & $\mathrm{mm}$ & 114 & 100 \\
\hline Width of rotor & $\mathrm{b}$ & $\mathrm{mm}$ & 80 & 75 \\
\hline Number of slit & & 8 & 4 \\
\hline Depth of slit & $\mathrm{mm}$ & 40 & 55 \\
\hline Thickness of slit & $\mathrm{mm}$ & 5.1 & 4.2 \\
\hline Slit setting angle & $\gamma$ & $\mathrm{deg}$. & 0 & 22 \\
\hline
\end{tabular}
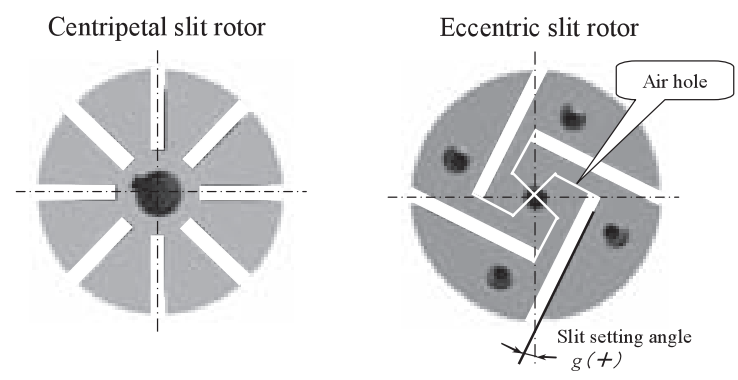

Fig. 3 Slit patterns of rotors
偏心スリットロータでは無潤滑（ドライ）条件の下でそれ ぞれ実験した. ブレード頂部の初期形状（円弧半径 $R$ ： $10 \mathrm{~mm})$ と表面粗さ $(\mathrm{Ra}: 15 \mu \mathrm{m})$ は稼働時間とともに摩耗し, ある特定の曲面に収斂するため, 実験は十分馴染んだ後に 行われた. ロータスリットとブレード厚のあそびは $0.2 \mathrm{~mm}$ 内である。

\section{4. 実験結果および考察}

エアポンプのブレード挙動を考察するに先立ち, その出 入速度 $v(\theta)$ を, ブレードの回転角度 $\theta$ に対する突出し量 $c(\theta)$ の変化率として定義する（式(1))。ここで, ブレード突出 し量 $c(\theta)$ とはロータスリット出口とシリンダ間の隙間であ り，ロータ偏心量eによって発生する (Fig. 2).

$$
v(\theta)=d\{c(\theta)\} / d \theta
$$

Fig. 4は, 突出し量 $c(\theta)$ と出入速度 $v(\theta)$ の理論計算例を極 座標で示したものである. 突出し量は, 偏心円状のサイク ルを呈する. 出入速度は突出し時と後退時で正負が逆転す るがその絶対值は対称なサイクルを描き, 最大值はブレー ドの最大突出し位置から \pm 90 度位相がずれることが分かる。 このような特性カーブは, 回転する偏心ロー夕の幾何学か ら容易に算出できる.

以下，デー夕はすべて極座標で表示され，中央にブレー ドの配置図が付されているが, 回転角度 $\theta$ とポンプ構造 （吸・排気ポートなど）の配置関係は全てFig. 4に準じてい る.なおAppendixに関連する記号表を記載した。

\section{1 シングルブレードによる摺動トルクサイクル}

シングルブレードによる摺動トルクサイクルの解析モデ ル計算值と実測值を, 求心スリットロータと偏心スリット ロータについて比較した.その所見をまとめると次のとりで ある.

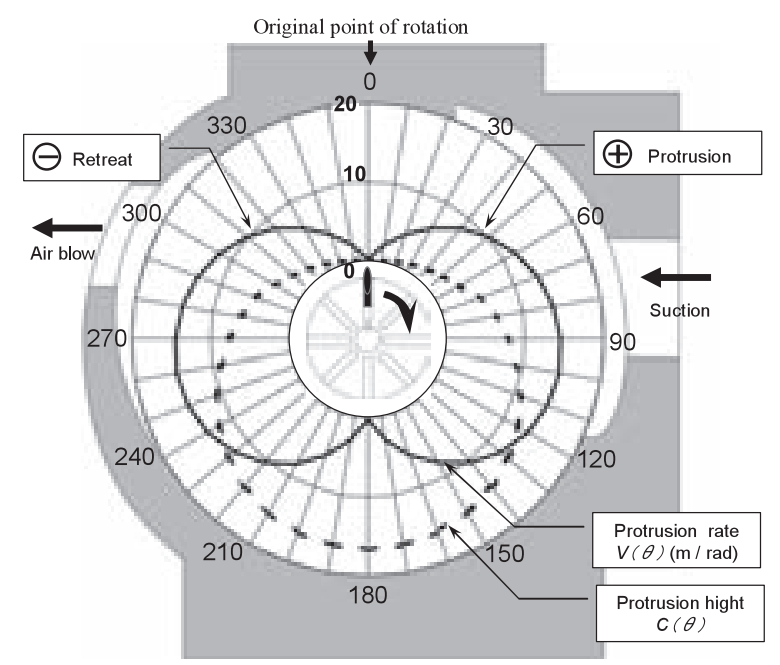

Fig. 4 Protrusion higth $C(\theta)$ and protrusion rate $v(\theta)$ of single blade (Theoretical results for a centripetal slit rotor) 
4.1.1 求心スリットロータの摺動トルク特性

ブレードはロータの回転 $N(\mathrm{rpm})$ が誘起する遠心力 $f_{C}$ によって, ロータスリットとの摩擦に抗して，その頂部を シリンダ壁へ押付けられる。 その垂直方向分力 $F_{N} に$ 滑り摩 擦係数 $\mu_{0}$ を乗じることによって摺動力 $F_{T}\left(=F_{N} \times \mu_{0}\right)$ を概 算できる.これらの数値 $F_{N}, F_{T}$, および合力 $F_{0}$ の間の力学 モデルが，可動翼型回転圧縮機や油圧ベーンポンプに対し て提案され2(2)33,5),6)，ロータスリットに打ける支点反力 $F_{1}$, $F_{2}$ の作用を考慮することによって, ブレードの出入に要す る摩擦力 $F_{B}\left(=F_{I B}+F_{2 B}\right)$ は理論的に定義されている. しか し，ブレード側面に生じる擦過痕観察1) から， $F_{B}$ の存在は 間接的に確認されるが，理論モデルにおける $F_{B}$ 数值の妥当 性を具体的に検討した例は見当たらない．

摩擦係数の効果; 本報では静力学的理論モデルの $1 つ^{3)}$ を参考に，エアポンプにおけるブレード摺動トルク式を誘 導し (Appendix参照)，その摺動トルクサイクルを具体的 に数值計算した。なおその際，ブレード頂部を円弧形状と し，シリンダ面との線接触を仮定している，その計算結果 の 1 例をFig.5に示す．同図では，シングルブレードを想 定しているので翼室圧の影響を無視し，摩擦係数 $\mu_{0}, \mu_{B}$ (Appendix参照)には常識的な数值を仮定している。この 解析モデル值はブレード突出し時に比べ後退時に数倍大き なトルク值の歪み円状サイクルを呈しており，最大突出し 量と最大後退速度（Fig. 4）の中間付近に極大值が存在す る (Fig. 5)。なぜなら, ブレードのスリット後退抵抗と突 き出し高さが摺動トルクを左右するために両者のピーク值 の中間あたりに最大トルクが現れるものと理解され，当然 のことながら，摩擦係数 $\mu_{0}, \mu_{B}$ による影響が大きいことは， 容易に推察できる。このように仮定された摩擦係数の下で のシミュレーション結果は比較的妥当な傾向を示している が, ブレードの動力学モデルの検討および穾摩擦係数の特 定が今後の課題である。な掕考までに，ブレード支点反 力 $F_{1}, F_{2}$ 抢よび接触角 $\alpha$ を゙ロと仮定し, 遠心力のみによ るブレード出入を想定した単純モデルによって求心スリッ トロータのシングルブレードに対する摩擦トルクサイクル

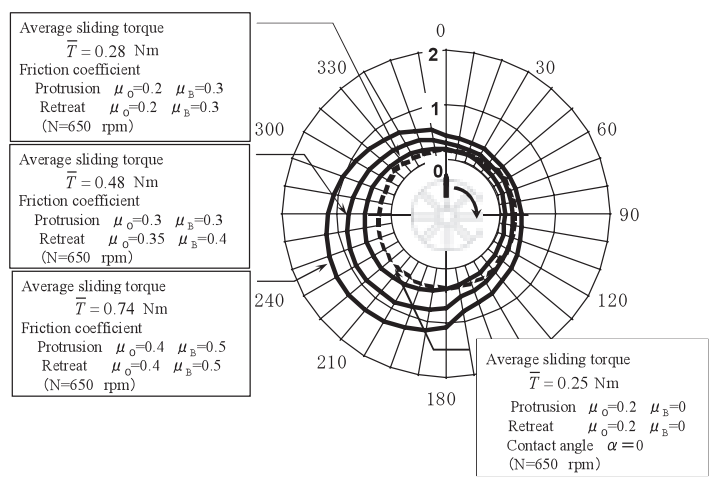

Fig. 5 Sliding torque by single blade (Theoretical results for a centripetal slit rotor)
を試算してみたフブレード重量：約 $0.012 \mathrm{~N} / 1$ 枚より，回 転数650rpmにおけるブレードの遠心力は，20～29N程度 となり平均值でも高々 $24 \mathrm{~N} に$ 過ぎない。この摺動トルクサ イクル（摩擦係数 $\mu_{0}=0.2$ を仮定）はFig. 5 (破線) に見る と抢りであり, 平均摩擦トルク $\bar{T}_{F}$ は約 $T_{F}=0.25 \mathrm{Nm}$ （最大摩 擦トルクは約 $0.35 \mathrm{Nm}$ ）となる.

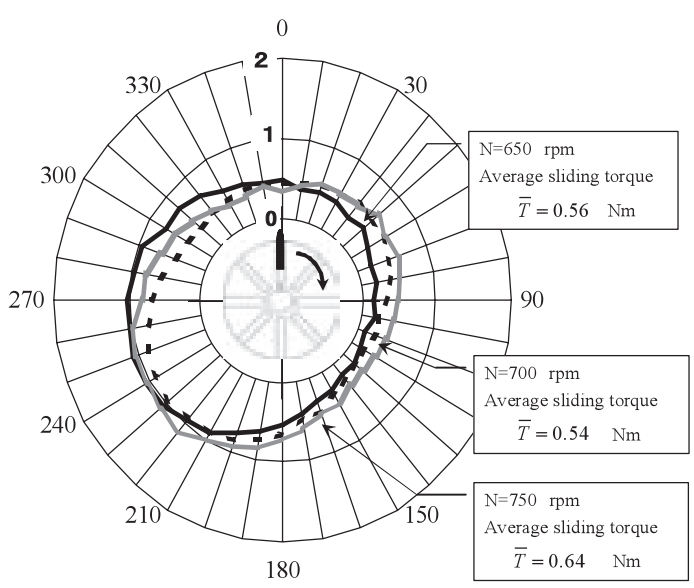

Fig. 6 Effects of rotation speed on sliding torque by single blade (measured value for a centripetal slit rotor)

またFig. 6にシングルブレードに扔ける駆動トルクの害 測值（Fig. 5に対応する回転数：650rpm）を示した．実測 值と解析モデル $\left(\mu_{B}=0\right)$ の数值はかなり乘離しているの がわかる。このことからも，ロータスリットとブレード間 の出入摩擦係数 $\mu_{B}$ が, 摺動卜ルクに極めて大きな影響を及 ぼすことが窥われる。

回転数（遠心力）の効果； ロー夕回転数に関して言え ば，回転数変化650～750rpmに伴う遠心力の変化量がせい ぜい $10 \mathrm{~N}$ と摺動抵抗の絶対值に比べ小さいものの, 理屈上 は遠心力が回転数の二乗に比例することから, 高速になる に伴い摺動トルクも相応に増加するはずである.

Fig. 6に示した回転数の違いによる効果の特性的傾向は 理論サイクル (Fig. 5) と近似しているが, 回転数の変化 に対して，650〜 750rpm程度では大きな差違が現れない. おそらく，前述のように摺動トルクの主体がブレードのス リット出入抵抗によって支配されているためと考えられる. しかし，回転数がある限界（本実験では600rpm辺り）以下 の低速度になると摺動トルクサイクルパターンの再現性が 急激に低下することが観察されることから，安定したブ レードの出入を保証するには，それより大きい回転数の望 ましいことが判明した．この原因はブレードに作用する遠 心力効果にしきい值が存在するものと想像される.

ロータスリット底の圧力効果 ; ブレードの出入に伴う ロータスリット底の隙間変化がその内圧を変動させ, 出入 運動の挙動に影響を及ぼすことは十分予想される。ロー夕 スリット底と翼室を繋ぐブレード通気溝（Fig. 2) はこの 圧力変化を緩和（自動調整）させる意図で考案された. 
Fig. 7 はブレード通気溝の有無によるシングルブレードの 摺動トルクを対比したもので，実測した 5 サイクル分の データを示している. 同図によると，平滑シングルブレー ドの方が通気溝を付したブレードに比べ，摺動トルクの平 均值 $(\bar{T})$ は小さいもののトルクサイクルの再現性に劣っ ている様子が現れており，このことは恐らくブレードの浮 き上りも含めてその出入の不安定さを示唆している. しか し，ブレード通気溝の得失はエアポンプの送風・吸気効率 との絡みで駆動トルクの絶対值も含めて議論されなければ ならないものと考える.

\section{1 .2 偏心スリットロータの摺動トルク特性}

まず，スリット角をロータ回転方向へプラス，その逆を マイナスと定めることにする (Fig. 3). ブレード摩擦力の うち後退べクトル分力の大きいことから, 理論上プラスス リット角の方がブレードの出入運動にとって有利のはずで ある。したがって，カーボンブレードを用いた偏心スリッ トロータのドライエアポンプでは，プラススリット角が採 用されることになる．偏心スリットロータに対する摺動卜 ルクの実測值の 1 例をFig. 8に示す. トルクの最大值が局

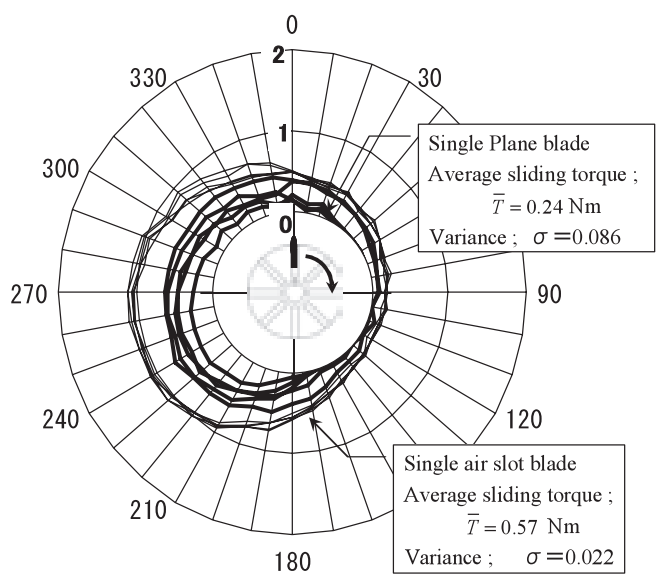

Fig. 7 Effects of air slots on slidimg torqur by single blade (measured value of serial 5 cycle curves for centripetal slit rotor)

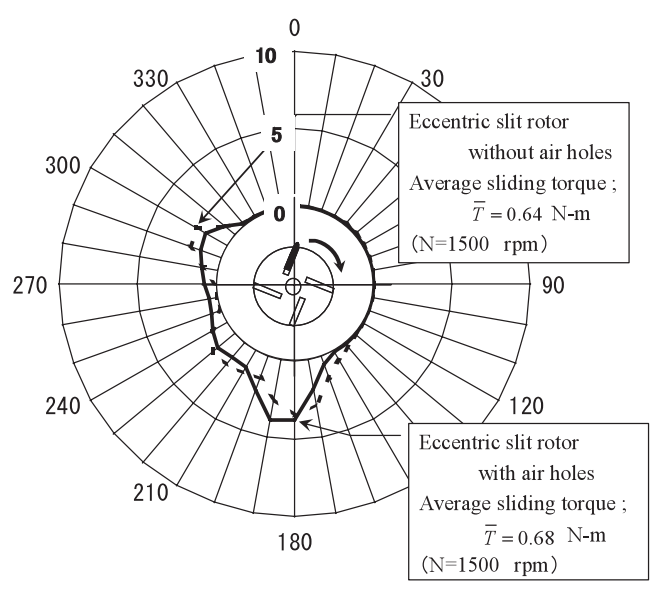

Fig. 8 Sliding torque by single blade on an eccentric slit rotor (measured value)
所に集中すると共に, その位置が求心ロータに比べ回転逆 方向側に偏る（位相が進む）傾向を示す。これは，ブレー ドがケーシング壁面へ傾斜接触するため, 最大突出し量 $C_{\text {max }}$ に対する回転位置が早まることによって生じる現象で あることは幾何学的にも理解できる.

Fig. 8では，シングルブレードの摺動トルクに対してロー 夕導通孔（Fig. 3) の効果も対比されている. 同図では両 者の明白な差は確認できない。すなわち，ロータスリット 底間に導通孔を設けても, 駆動トルクに大幅な変化が見ら れない.しかし，ブレード側面の通気溝と同様，マルチブ レードにおいて導通孔もまた出入運動の安定性に優位に作 用する傾向が確認された.

\section{2 マルチブレードにおけるブレードの出入挙動}

4.2 .1 翼室圧が求心スリットロータ／ブレード挙動へ及ぼ す影響

シングルブレードの実測したデータの摺動トルクサイク ルをブレードの取付位置だけ位相をずらしてその枚数分を 重ね合わせるという線形加法モデルは，エアポンプの摺動 トルク特性を考察する上で 1 つ手がかりを与えてくれる. この手法によってマルチブレードにおける摺動トルクサイ クルをシミュレーションした 1 例が, Fig. 9 (A) である.

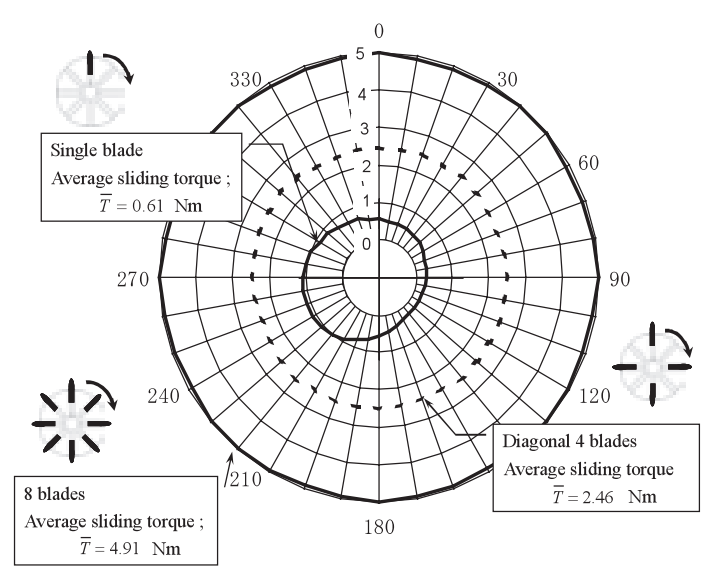

(A) Simulated value by summing up single blade torque

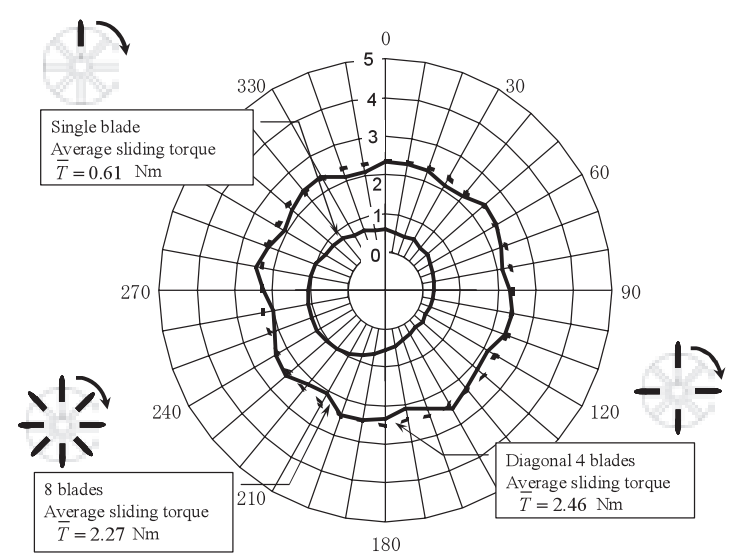

(B) Measured values

Fig. 9 Sliding torque by multi-blades with air slots 


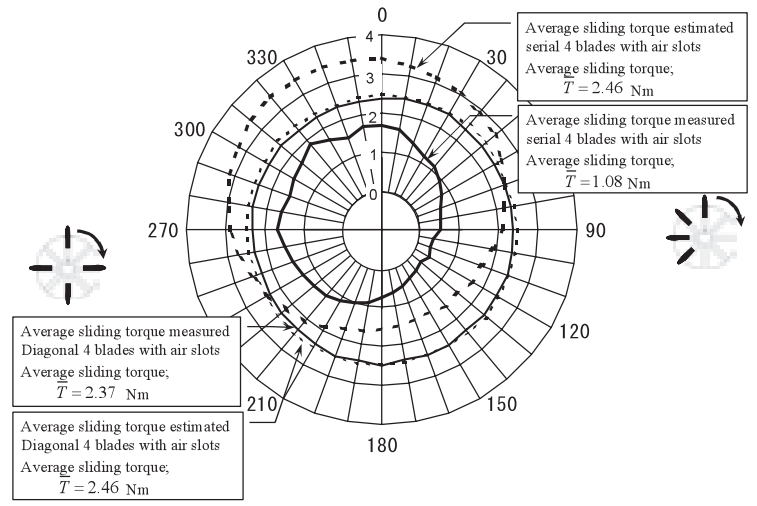

Fig. 10 Array effect of 4 blades on sliding

また比較のためFig. 9 （B）に，この実測トルクサイクルを 示している. 両図の結果を対比させて見ると, シングルブ レードの加法モデルによるシミュレーション結果は実測值 と対角 4 枚ブレード配列（翼室圧は生じない）ではその傾 向がほぼ一致しているのに対し，8枚ブレード（翼室圧が 発生) では実測值がシミュレーションより遙かに小さな数 值を示している。このように顕著な相違は翼室圧によって もたらされる効果と予想される. 恐らく, マルチブレード におけるブレード出入の円滑性は隣り合う翼室圧差に敏感 に反応し影響を受けたものと考えられる。したがって，シ ングルブレードによる摺動トルクサイクルのブレード枚数 に応じた単純加法性は, 翼室圧の生じるケースでは成立し 難いということになる.この結論の妥当性を検証する目的 で，ブレードの配列による摺動トルク効果を実測した。 Fig. 10は， 4 枚マルチブレードについて，連続 4 枚配列 （翼室圧が発生）と対角 4 枚配列（翼室圧の変化なし）を 実測值と単純加法モデル值をそれぞれ対比させて示したも のである，前者（連続配列）は隣り合う翼室に生じた圧力 の差圧がロータスリットにおける反力 $F_{1}, F_{2}$ (Appendix参 照）に少なからぬ影響を及ぼした結果，ロータスリットで のブレード拘束を緩めその出入が円滑化し, 加法モデル值 より実測值が大幅に低下したものと推測される。これに対 して, 後者（対角配列）はその圧力差が生じないことから, シングルブレードの単純な重ね合わせシミュレーションと 良い一致を見たものと解釈できる.

以上の結果より，ブレード出入の円滑化にとって，ロー タスリットの寸法形状や表面粗さ，エッジ品質などが重要 な影響因子となり得るものと推察される。とりわけ，マル チブレードにおける通気溝の調圧効果には，期待が大きい， Fig. 11には平滑ブレードと通気溝付きブレードの 8 枚ブ レードにおける摺動トルクを比較している. シングルブ レードでは平滑ブレードの摺動トルクが通気溝付きブレー ドに比べかなり小さかったにもかかわらず，8枚ブレード になると通気溝付きブレードの方が結果として，トルクサ イクルが安定し, 絶対值も若干小さくなる傾向を示してい る.

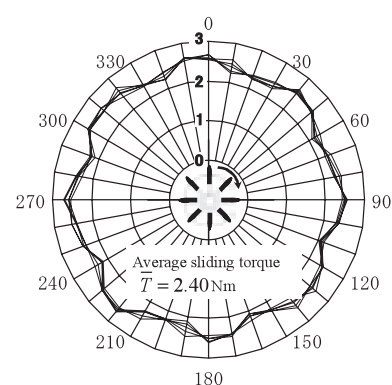

(A) Plane blade

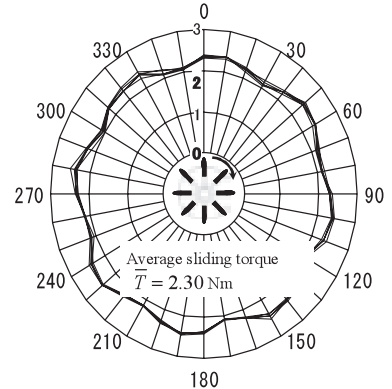

(B) Air slot blade
Fig. 11 Stability of sliding torque cycle for multi-blades (serial 5 cycle curves)

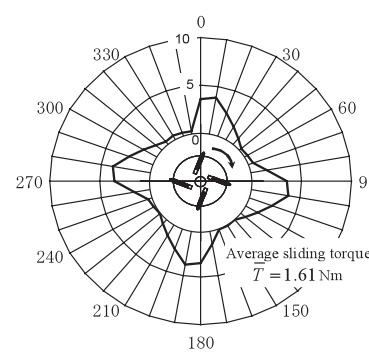

(A) Value estimated by summing up single blade torque

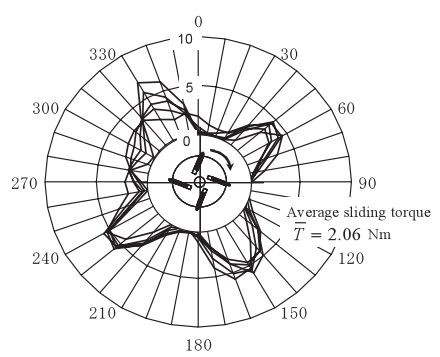

(B) Measured values (serial 5 cycle curves)
Fig. 12 A sliding torque cycle curve by multi-blades (an eccentric slit rotor without air holes)

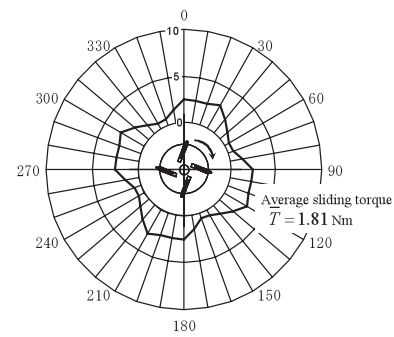

(A) Value estimated by summing up single blade torque

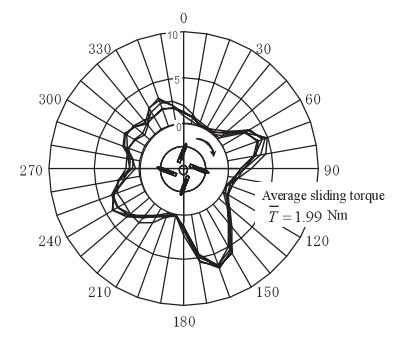

(B) Measured values (serial 5 cycle curves)
Fig. 13 A sliding torque cycle curve by multi-blades (an eccentric slit with air holes)

4.2 .2 偏心スリットロータ／ブレード挙動へ及ぼす翼室圧 の影響

偏心スリットロータによるマルチブレードの駆動トルク 予想にも，シングルブレードによる摺動トルクの加法シ ミュレーションを利用できる．Fig. 12(B)より明らかなよう に, 平均実測トルクおよびその極大值は加法モデル Fig. 12(A)による予測值よりかなり大きく, トルクサイクル 間のばらつきも著しい.すなわちロータスリット底の導通 孔無しでは, ブレード出入運動が安定しにくい傾向を示し ているといえる

このような所見をもとに, ブレードの出入の円滑化を図 る対策としてロータスリット底間を導通させることによる 
調圧効果を予見することができる. 例えば，ロータサイド にスリット底を連結するスロットを同心円状に設ける試み がなされた例がある。本研究では，ロータスリット底間を 繋ぐ導通孔を設計した，すなわち，ブレードの出入によっ て生じるロータスリット底容積の変化がもたらす背圧変動 をこの導通孔によって緩和することにより，ブレードの出 入を円滑にし，摺動トルクの低減を図ろうとするものであ る. Fig. 12，13より導通孔有無の効果を対比すると，導通 孔によって 1 サイクル中のトルク変動が緩和され, 安定性 も増している様子が認められる。 このことよりロータス リット底に形成される密封隙間内の背圧を開放するために 導通孔を設けることは, ブレードの円滑な出入挙動に一応 の効果を認めることができたと考える5).

\section{5. 結言}

本研究では, 以下の結論を得た.

(1) エアポンプにおける軸駆動トルクは, 理屈上は, ブ レードに作用する遠心力 $f_{C}$ がもたらす摺動抵抗 $F_{T}(=$ $\left.F_{N} \times \mu_{0}\right)$ によって支配されるはずである. しかし，現害 の摺動抵抗はそのような単純計算値よりも大きい。この 原因は，ブレードとロータスリット間の摩擦によるブ レード出入の拘束に因ることが，本実験によって推定さ れた。

（2）ブレードとシリンダ壁間の摺動トルクはロータの回転 角度に連動してサイクル変化する，その大きさはブレー ドの突出し量とその変化率（出入速度）に影響され，両 者の極値の中間付近で最大となる傾向を示す.

（3）求心スリットロータと偏心スリットロータでは, シン グルブレードのトルク極大值の位置に位相差が生じる. これはスリット角がもたらすものと考えられる。

(4) マルチブレードに扔いて, 翼室圧はブレード出入挙動 にとって大きな影響因子となる。

(5) ブレード通気溝抒よび導通孔によるロータスリット底 間自動調圧作用は, ブレード摺動摩擦の軽減にとって有 効な対策となり得る.

\section{謝辞}

本研究の実施に当たり, 有益な助言を賜った芝浦工業大 学名誉教授 柴田順二氏に深甚の謝意を表します.

\section{参 考 文 献}

1) 植木, 稲葉, 柴田: 真空・圧縮ポンプのベーンとケー シング摩耗に関する基礎研究（その 2 ), 日本トライ ボロジー学会トライボロジー会議予稿集, p. 95-96 (2002)
2 ）伊藤，他：容積型圧縮機，産業図書，p. 184（1979）

3 ）上野, 岸岡, 森本: 可変容量型ベーンポンプの特性に 関する研究（第 2 報 ベーンによる摩擦卜ルク特性に ついて), 油圧と空気圧, Vol. 9, No.1, p. 38-45 (1978)

4) 植木, 稲葉, 柴田: 可動翼型送風・圧縮ポンプのベー ン挙動観察, (社)フルードパワーシステム 平成18年春季 講演会, p. 85-87 (2006)

5 ) 植木, 稲葉, 柴田：可動翼型送風・圧縮ポンプおける ロー夕溝間の導通孔の効果, (社)日本フルードパワーシ ステム 平成19年春季講演会, p. 158-160（2007）

6 ）稲熊, 日比：ベーンポンプの摩擦トルク特性, 油圧と 空気圧，Vol. 25，No.7， p. 843-849 (1994)

\section{Appendix}

3つの力のつり合い方程式（ブレード出入り方向とその 直交方向の力のつり合い掠よびモーメントのつり合い）か ら，ブレード摺動トルクTは，次のとおり導かれる。

$$
\begin{aligned}
T & =F_{0} \cdot \cos \alpha \cdot\left(\sin \alpha+\mu_{0} \cdot \cos \alpha\right) \cdot \rho \\
& =\left(W+F_{0}\right) \frac{\rho}{\mu_{\mathrm{B}}} \\
& =\frac{W \cdot\left\{\cos \alpha \cdot\left(\sin \alpha+\mu_{0} \cdot \cos \alpha\right)\right\} \cdot \rho}{\cos \alpha \cdot\left(\sin \alpha+\mu_{0} \cdot \cos \alpha\right) \cdot \mu_{\mathrm{B}}-1}
\end{aligned}
$$

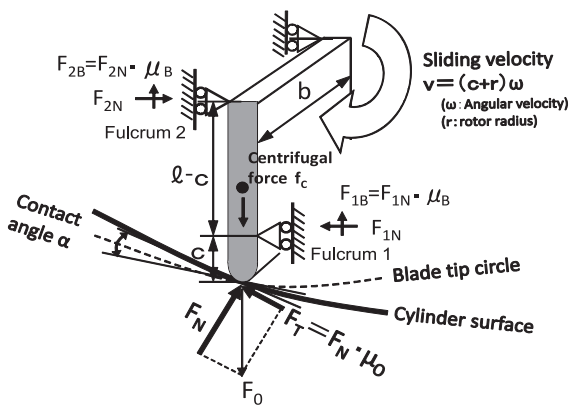

[記号表]

$f_{C}:$ 遠心力 $(\mathrm{N})$

$\rho:$ ロー夕中心からケーシング接触面までの距離（mm)

$\alpha$ :ケーシングとブレードの接触角（度）

$\mu_{0}:$ ケーシングとブレードの摩擦係数

$\mu_{B}:$ ロータ溝とブレードの摩擦係数

(前進 + , 後退 - )

$F_{o}:$ ケーシング反力 $(\mathrm{N})$

$F_{N} ; F_{T}$ : ケーシング壁面分力 $(\mathrm{N})$

$F_{l}, F_{I N}, F_{I T} ;$ 支点 1 各反力 $(\mathrm{N})$

$F_{2}, F_{2 N}, F_{2 T}$ : 支点 2 各反力 $(\mathrm{N})$

$W:$ ブレードの作用する遠心力 $(\mathrm{N})$ 